\title{
Sistem Ekonomi Perbankan Berlandaskan Bunga (Analisis Perdebatan Bunga Bank Termasuk Riba Atau Tidak)
}

\author{
Abdul Haris ${ }^{1)}$, Muhammad Tho'in ${ }^{2)}$, Agung Wahyudi ${ }^{3)}$ \\ Email:abdul.haris@gmail.com
}

\begin{abstract}
Bank interest is the remuneration provided by the bank based on conventional principles to customers who buy or sell their products. Bank interest can be in the form of interest on deposits and interest on the loan. The purpose of this study is to determine the various opinions and about the interest position of usury bank or not. The research method used in this research topic is in the form of study or literature study obtained from various sources of books, journals, and other sources that are very relevant to the research topic. The results show that most scholars and scholars claim that the bank interest is the same as usury, so the law of bank interest is haram. But there is also a judge that bank interest is different from interest, so bank interest is okay, especially some Middle Eastern clerics supported by secular-minded economic experts.
\end{abstract}

Keywords: economic system, bank interest, usury

\section{PENDAHULUAN}

Sistem ekonomi Islam sampai saat ini masih diperdebatkan keberadaannya, dimana apakah itu sistem ekonomi Rasulullah Saw dan para sahabat atau suatu sistem yang baru saja dikembangkan. Tetapi yang jelas perdebatan itu menegaskan bahwasanya sistem ekonomi Islam adalah sistem ekonomi yang berlandaskan pada sumber-sumber hukum Islam terutama al-Qur'an dan Sunnah.

Umat Islam dalam setiap aktifitas hidupnya harus senantiasa berlandaskan pada aturan-aturan yang telah dibuat oleh Allah Swt dan Rasulullah Saw agar dapat mencapai kebahagian di dunia dan kebahagiaan di akhirat kelak. Salah satunya adalah aktifitas kegiatan ekonomi yang dilakukannya.

Jika dikaji bahwasanya kegiatan ekonomi yang ada dari waktu ke waktu terus mengalami perkembangan yang sangat signifikan, yang dulu kegiatan ekonomi tersebut tidak ada, sekarang justru ada dan begitu juga sebaliknya dulu tidak ada sekarang ada. Pada masa pemerintahan baginda Rasulullah tidak ada yang namanya uang kertas, maupun suatu lembaga keuangan semacam perbankan yang ada saat ini. Persoalan baru muncul dalam fiqh, terutama fiqh muamalah ketika mengkaji suatu pengertian riba dihadapkan kepada persoalan perbankan. Di satu sisi, bunga bank terperangkap dalam kriteria riba yang jelasjelas diharamkan oleh Allah dan Rasulullah, tetapi dalam sisi yang lain bank mempunyai fungsi sosial yang sangat besar bahkan dapat dikatakan bahwa tanpa adanya bank, ekonomi suatu bangsa akan mengalami suatu hambatan yang luar biasa untuk berkembang terlebih menjadi negara maju. 
Berbicara mengenai bank dalam pandangan Qur'an dan Sunnah, tidak bisa dilepaskan dari perdebatan dan perbedaan tentang bunga, dimana oleh sebagian ulama bunga dianggap sebagai riba yang diharamkan dalam al qur'an secara qat'i. Perdebatan yang serius tentang apakah bunga bank itu termasuk riba atau bukan riba, telah berlangsung lama dan sampai sekarang masih hangat diperbincangkan bahkan menimbulkan pendapat pro dan pendapat kontra di kalangan umat Islam sendiri. Tentunya mereka semua antara yang pro dan kontra tidak dapat dibenarkan $100 \%$ dan disalahkan pula $100 \%$. Adanya suatu keberagaman pendapat serta interpretasi tentang riba yang berkaitan dengan bunga bank, hal itu disebabkan karena adanya suatu perbedaan pendekatan yang digunakan oleh masih-masing dalam menganalisis serta menafsirkan ayat-ayat riba yang ada di dalam al-Qur'an. Demikian pula ketika menengok kepada hadis, karena pada zaman nabi tidak ada lembaga keuangan seperti perbankan yang membungakan uang.

Dalam berbagai literatur klasik yang ada tidak pernah dijumpai pembahasan yang mengkaitkan antara bunga perbankan dan riba. Sebab lembaga perbankan tidak dijumpai pada zaman klasik. Oleh sebab itu, pembahasan mengenai posisi bunga bank riba atau tidak sangat menarik untuk dipelajari dan diperbincangkan. Sehingga penelitian ini akan mengulas bagaimana sistem ekonomi perbankan berlandaskan bunga (Analisis Perdebatan Bunga Bank).

\section{TUJUAN PENELITIAN}

Tujuan dari penelitian ini adalah untuk mengetahui berbagai pendapat dan mengenai posisi bunga bank riba atau tidak.

\section{METODE PENELITIAN}

Metode penelitian sistem ekonomi perbankan berlandaskan bunga yang digunakan dalam topik penelitian ini adalah berupa kajian atau studi pustaka yang diperoleh dari berbagai sumber buku, jurnal, maupun sumber-sumber lain yang sangat relevan dengan topik penelitian ini.

\section{KAJIAN PUSTAKA}

\section{Sistem Ekonomi}

Menurut Gilarso (2004), Sistem ekonomi adalah keseluruhan tata cara untuk mengoordinasikan perilaku masyarakat (para produsen, konsumen, pemerintah, bank, dan sebagainya) dalam menjalankan kegiatan ekonomi (produksi, distribusi, konsumsi, investasi, dan sebagainya) sehingga terbentuk satu kesatuan yang teratur dan dinamis sehingga kekacauan dalam bidang ekonomi dapat dihindari.

Menurut Dumairy (1996), Sistem ekonomi adalah suatu sistem yang mengatur serta menjalin hubungan ekonomi antar manusia dengan seperangkat kelembagaan 
dalam suatu tatanan kehidupan. Selanjutnya dikatakannya pula bahwa suatu sistem ekonomi tidaklah harus berdiri sendiri, tetapi berkaitan dengan falsafah, padangan dan pola hidup masyarakat tempatnya berpijak. Sistem ekonomi sesungguhnya merupakan salah satu unsur saja dalam suatu supra sistem kehidupan masyarakat. Sistem ekonomi merupakan bagian dari kesatuan ideology kehidupan masyarakat di suatu negara.

Sedangkan menurut Gregory Grossman (1995), bahwa sistem ekonomi adalah sekumpulan komponen-komponen atau unsurunsur yang terdiri dari atas unit-unit ekonomi, serta lembaga-lembaga ekonomi yang bukan saja saling berhubungan dan berinteraksi melainkan juga saling menopang dan memengaruhi.

\section{Bank dan Perbankan}

Pengertian bank menurut UU No. 7 Tahun 1992 tentang perbankan sebagaimana yang telah diubah dengan UU No. 10 Tahun 1998 dimana "Bank adalah badan usaha yang menghimpun dana dari masyarakat dalam bentuk simpanan dan menyalurkannya kepada masyarakat dalam rangka meningkatkan taraf hidup rakyat banyak.“

Menurut pendapat yang dikemukakan oleh Kasmir (2003), Bank secara sederhana dapat diartikan lembaga keuangan yang kegiatan utamanya adalah menghimpun dana dari masyarakat dan menyalurkan kembali Jurnal Akuntansi Dan Pajak, Vol 13, No. 01, Juli 2012 dana tersebut ke masyarakat serta memberikan jasa bank lainnya.

Sedangkan pengertian dari perbankan itu sendiri adalah segala sesuatu yang menyangkut tentang bank mencakup kelembagaan, kegiatan usaha, serta cara proses dalam melaksanakan kegiatan (Muljono, 1994).

\section{Bunga Bank}

Bunga bank dapat diartikan dan dimaknai sebagai balas jasa yang diberikan oleh pihak bank yang berdasarkan prinsip konvensional kepada nasabah yang membeli atau menjual produknya, dalam hal ini tentunya produk-produk perbankan. Bunga juga dapat diartikan sebagai harga yang harus dibayar kepada pihak nasabah (yang memiliki simpanan) dengan yang harus dibayar oleh pihak nasabah kepada bank (nasabah yang mendapatkan pinjaman).

Dalam berbagai kegiatan perbankan ada dua macam bunga yang diterapkan dan diberikan oleh pihak bank kepada para nasabahnya, dua macam bunga bank tersebut yaitu sebagai berikut:

1. Bunga bank berupa bunga simpanan, yaitu bunga yang diberikan oleh pihak bank kepada nasabah sebagai balas jasa bagi nasabah yang menyimpan uangnya di bank tersebut. Bunga simpanan fungsinya untuk memberikan rangsangan kepada calon nasabah agar mau menyimpan uangnya di 
bank. Atau dengan kata lain bunga simpanan suatu harga yang harus dibayar pihak bank kepada nasabahnya. Sebagai contoh bunga tabungan, jasa giro, maupun bunga deposito bank.

2. Bunga bank berupa bunga pinjaman, adalah bunga yang diberikan kepada para peminjam kepada pihak bank karena adanya peminjaman. Dengan kata lain bunga pinjaman adalah harga yang harus dibayar oleh nasabah peminjam kepada pihak bank seperti bunga kredit dan lain sebagainya.

Dari berbagai definisi diatas, sangatlah jelas bahwasanya bunga bank adalah tambahan yang disebabkan karena adanya simpanan maupun pinjaman antara pihak nasabah dan pihak bank dari pokok simpanan dan pokok pinjaman yang dilakukan atau ditransaksikan.

\section{Riba}

Pendapat yang dikemukakan oleh para ahli fiqih yang berkaitan dengan berbagai pengertian atau definisi riba, antara lain sebagai berikut. Menurut Al-Mali pengertian riba adalah akad yang terjadi atas pertukaran barang atau komoditas tertentu yang tidak diketahui perimbagan menurut syara', ketika berakad atau mengakhiri penukaran kedua belah pihak atau salah satu dari keduanya.

Kemudian Abdul Rahman Al-Jaziri mengemukakan pendapatnya tentang pengertian riba sebagai berikut. Riba adalah akad yang terjadi dengan pertukaran tertentu, tidak diketahui sama atau tidak menurut syara' atau terlambat salah satunya.

Sedangkan menurut pendapat Syeikh Muhammad Abduh bahwa pengertian riba adalah penambahan-penambahan yang disyaratkan oleh orang yang memiliki harta kepada orang yang meminjam hartanya (uangnya), karena pengunduran janji pembayaran oleh peminjam dari waktu yang telah ditentukan.

\section{PEMBAHASAN}

Ada tiga pendapat tentang persoalaan apakah bunga bank itu sama dengan riba yaitu: Pertama, bunga bank adalah riba dan karenanya dianggap haram; Kedua, membolehkan bunga karena dianggap tidak sama dengan riba yang diharamkan oleh syariat agama Islam; dan Ketiga, bunga bank haram tapi karena belum ada jalan keluar untuk mengindarinya, maka diperbolehkan.

Para ulama maupun para cendekiawan muslim masih memiliki perbedaan pendapat tentang hukum bunga bank diantaranya: $\mathrm{Abu}$ zahrah, abu 'ala al-Maududi Abdullah al'Arabi dan yusuf Qardhawa mengatakan bahwasanya bunga bank konvensional itu termasuk dalam golongan riba nasiah yang dilarang oleh Islam. sehingga umat Islam dilarang melakukan kegiatan muamalah serta melakukan transaksi dengan bank yang 
menggunakan sistem bunga dalam berbagai transaksi yang dilakukan, terkecuali hal tersebut terjadi dalam keadaan darurat sehingga ada rukhsah atau keringanan.

$$
\text { Sedangkan pandangan Yusuf }
$$

Qardhawi, bahwasanya dalam hal tersebut di atas, tidak mengenal istilah darurat sehingga tidak ada yang namanya rukhsah, sehingga beliau berpendapat tegas mengharamkan adanya transaksi dengan bank konvensional (sistem bunga) karena sama dengan riba. Pendapat Yusuf Qardhawi tersebut dikuatkan oleh pendapat Al-Syirbashi, menurutnya bahwa bunga bank konvensional yang didapatkan seseorang yang melakukan penyimpanan uang di bank adalah riba tanpa melihat banyak sedikitnya bunga yang diperoleh tersebut. Islam tegas yang namanya haram meskipun bunga itu sedikit tetap haram. Namun yang terpaksa, maka agama itu membolehkan meminjam uang di bank itu dengan bunga.

kebanyakan ulama' sepakat bahwa bunga bank adalah riba, oleh karena itulah hukumnya haram. Berbagai forum ulama internasional mengeluarkan adanya keputusan berupa fatwa pengharaman bunga bank.

Dalam Islam, hukum bagi orang-orang yang melakukan riba sudah jelas (jalli) dilarang Allah SWT dan Rasulullah SAW. Begitu pula dengan bunga yang diterapkan pada perbankan, dalam praktik sehari-harinya sistem bunga yang ada di perbankan (bank konvensional) cenderung menyerupai atau bahkan sama dengan riba, yaitu melipatgandakan pembayaran baik dari sisi nasabah maupun dari sisi atau pihak bank. Padahal dalam Islam sendiri sudah jelas pula bahwa hukum hutang-piutang haruslah dengan ukuran yang sama. Sehingga jumlah yang diutangkan kepada peminjam harus dikembalikan dalam jumlah yang sama kepada yang memberikan utang atau pinjaman.

Penjelasan ini sejalan dengan pendapat Syaikh Sholih bin Ghonim As Sadlan, dimana seorang Mufti Saudi Arabia bernama Syaikh Muhammad bin Ibrahim rahimahullah mengemukakan bahwa pinjaman yang diberikan oleh bank dengan tambahan (bunga) tertentu sama-sama disebut riba.

"Secara hakekat, walaupun (pihak bank) menamakan hal itu qord (utang piutang), namun senyatanya bukan qord. Karena utang piutang dimaksudkan untuk tolong menolong dan berbuat baik. Transaksinya murni non komersial. Bentuknya adalah meminjamkan uang dan akan diganti beberapa waktu kemudian. Bunga bank itu sendiri adalah keuntungan dari transaksi pinjam meminjam. Oleh karena itu yang namanya bunga bank yang diambil dari pinjam-meminjam atau simpanan, itu adalah riba karena didapat dari penambahan (dalam utang piutang). Maka keuntungan dalam pinjaman dan simpanan boleh sama-sama disebut riba." (Al Fiqh" hal. 398, terbitan Dar Blancia, cetakan pertama, $1424 \mathrm{H}$ ).

Ulama yang berada di Timur Tengah di dukung pula beberapa orang pakar ekonomi di negara-negara yang memiliki paham sekuler, mereka berpendapat bahwasanya riba tidaklah 
sama dengan bunga bank, sehingga bunga bank diperbolehkan atau boleh-boleh saja. Seperti Mufti Mesir Dr. Sayid Thantawi yang berfatwa tentang bolehnya sertifikat obligasi yang dikeluarkan Bank Nasional Mesir yang secara total masih menggunakan sistem bunga, dan ahli lain seperti Dr. Ibrahim Abdullah anNashir. Doktor Ibrahim dalam buku Sikap Syariah Islam terhadap Perbankan mengatakan, "Perkataan yang benar bahwa tidak mungkin ada kekuatan Islam tanpa ditopang dengan kekuatan perekonomian, dan tidak ada kekuatan perekonomian tanpa ditopang perbankan, sedangkan tidak ada perbankan tanpa riba. Ia juga mengatakan, "Sistem ekonomi perbankan ini memiliki perbedaan yang jelas dengan amal-amal ribawi yang dilarang Al-Qur'an yang Mulia. Karena bunga bank adalah muamalah baru, yang hukumnya tidak tunduk terhadap nash-nash yang pasti yang terdapat dalam Al-Qur'an tentang pengharaman riba”. Mr. Kasman Singodimedjo berpendapat, sistem perbankan modern diperbolehkan karena tidak mengandung unsur eksploitasi yang dzalim, oleh karenanya tidak perlu didirikan bank tanpa bunga. A.Hasan Bangil, tokoh Persatuan Islam (PERSIS), secara tegas menyatakan bunga bank itu halal karena tidak ada unsur lipat gandanya. Prof.Dr.Nurcholish Madjid berpendapat bahwa riba di mengandung unsur eksploitasi satu pihak kepada pihak lain, sementara dalam perbankan (konvensional) Jurnal Akuntansi Dan Pajak, Vol 13, No. 01, Juli 2012 tidaklah seperti itu. Dr.Alwi Shihab dalam wawancaranya dengan Metro TV sekitar tahun 2004 lalu, juga berpendapat bunga bank bukanlah riba. (masfufah, 2012) http://fhufah.blogspot.co.id/2012/07/pendapatulama-tentang-bunga-bank.html

\section{KESIMPULAN}

Hasil penelitian menunjukkan bahwa sebagian besar ulama dan cendekiawan muslaim menyatakan bahwa bunga bank sama dengan riba, jadi hukum bunga bank adalah haram. Tetapi ada juga yang menilai bahwa bunga bank berbeda dengan bunga, sehingga bunga bank boleh-boleh saja saja, terutama beberapa ulama Timur tengah yang didukung para pakar ekonomi yang berpaham sekuler.

\section{Daftar Pustaka}

Al Fiqh" hal. 398, terbitan Dar Blancia, cetakan pertama, $1424 \mathrm{H}$

Dumairy. 1996. Perekonomian Indonesia. Jakarta: Erlangga.

Gilarso 2004. Pengantar Ilmu Ekonomi Makro. Yogyakarta: Kanisius.

Gregory Grossman. (1995). Sistem-sistem ekonomi. Cetakan ketiga. Jakarta: PT Bumi Aksara

http://fhufah.blogspot.co.id/2012/07/pendapatulama-tentang-bunga-bank.html (diakses pada juli 2012.

Kasmir. 2003. Bank Dan Lembaga Keuangan lainnya. Jakarta: PT Raja Grafindo Persada

Teguh Pudjo, Muljono, 1994, Bank Auditing: Petunjuk Pemeriksaan Bank, edisi keempat, Jakarta: Penerbit Djambatan.

Undang-Undang U No. 7 Tahun 1992

Undang-Undang No. 10 Tahun 1998 